\title{
Yoram Tsafrir
}

\author{
(Jan. 30, 1938 - Nov. 22, 2015)
}

based on obituaries written in Hebrew by Y. Patrich and R. Talgam (translated by Y. Goel) and in English by C. Dauphin (see IEJ 66 [2016] 120-22, SCI 35 [2016] 163-66, and PEQ 148 [2016] 5-7

Yoram Tsafrir combined archaeology and history at the Hebrew University of Jerusalem, receiving his B.A. in 1964 and his Ph.D. in 1976. His mentor was Michael Avi-Yonah (1904-74). For many years (1968-94) he served on the editorial board of Qadmoniot, published by the Israel Exploration Society, and (1978-86) on that of Cathedra, published by the Yad Izhak Ben-Zvi Institute. He headed the Ben-Zvi Institute for the Research of Eretz Israel from 1976 to 1983. He was long a member of the Council of the Israel Exploration Society and a regular participant in its conferences in Israel and abroad, both as a lecturer and a guide on archaeological tours. For 21 years (1989-2010) he was a member of the Archaeological Council and its Licensing Committee. Elected to membership of the Israel Academy of Sciences and Humanities in 2001, he was appointed to prepare a report on the state of archaeology in the country, which was presented early in 2015 and made public. Not only was he closely involved in all aspects of archaeology in Israel, including archaeological surveys, excavations, policy-making and interaction

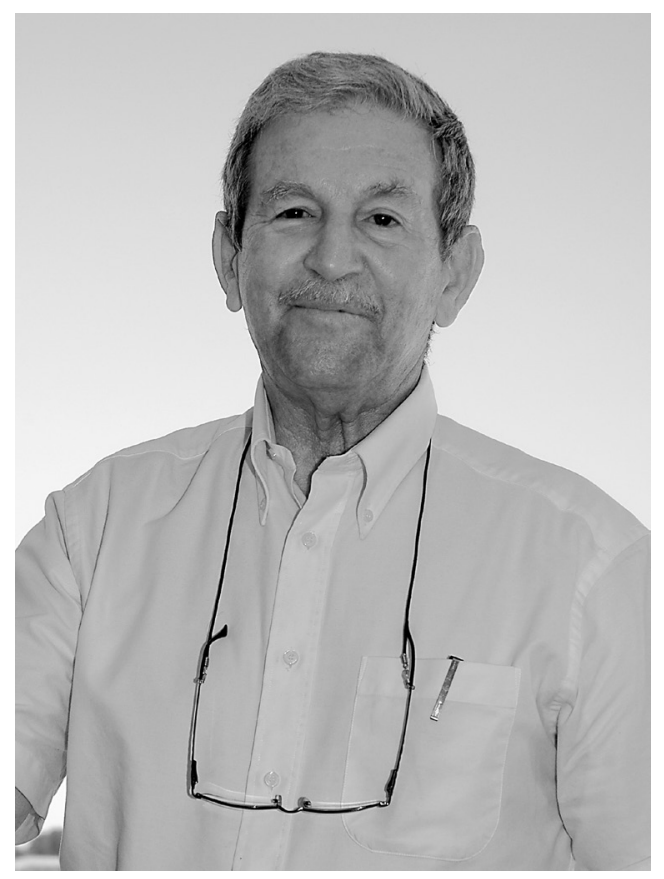
with the non-academic community, but he greatly influenced them in many ways. He was actively involved in the preservation of archaeological sites and in making them accessible to the public. He was opposed to what he believed to be the penetration of political interests into archaeological undertakings. He did much to enhance the prestige of Israeli archaeology both at home and abroad.

His research reflects the diverse ethnic, religious and cultural composition of the local population from the Hellenistic through the Umayyad periods. He made outstanding achievements in four major areas of research on the Roman and Byzantine periods:

\section{Jerusalem}

His Ph.D. dissertation (Zion: the southwestern hill of Jerusalem and its place in the urban development of the city in the Byzantine period) was written in the years immediately following the Six-Day War. It is a model of synthesis between analysis of the findings of many archaeological expeditions conducted since the 19th c. and the numerous literary sources. It served as a new point of departure for understanding the urban development of Jerusalem in the period and a basis for evaluating findings by the more recent excavations, including those of B. Mazar and N. Avigad. After 1974 he served as academic adviser to Avi-Yonah's model of Jerusalem in Second Temple times, which was transferred from the grounds of the Holyland Hotel to the Israel Museum in 2006. The three chapters written by him (the third with L. Di Segni) in The history of Jerusalem: the Roman and Byzantine period are essential. Other important studies dealt with the walls erected by Nehemiah and the Seleucid Akra.

\section{Churches}

Noteworthy excavations were conducted at Rehovot-in-the-Negev/Kh. Ruheibe (churches, dwellings, a caravansarai and cemeteries), at Horvat Berachot (a pilgrim church) on the edge of the Judaean Desert, with the late Y. Hirschfeld, and at Horvat Beit Loya (a church, olive oil and wine presses, and burial complex), with J. Patrich. He published detailed reports on the excavations, but also studies dealing with archaeological and historical issues related to a specific church, such as Jerusalem's Nea Church. He was commissioned to write an article for the Cambridge world history of religious architecture, which is now in press. 


\section{Historical geography in the Hellenistic, Roman and Byzantine periods}

Tsafrir completed Avi-Yonah's Gazetteer of Roman Palestine in 1976. An exhaustive project undertaken with L. Di Segni for the Israel Academy of Sciences and Humanities developed an Onomasticon of Iudaea Palaestina and Arabia in the Greek and Latin sources, comprising the geographical names and terms mentioned in all the written Greek and Latin sources relevant to the period from the conquest by Alexander of Macedon until the Islamic conquest. This is not merely a listing: each entry includes the full text of the sources in the original language and in translation; the information is then complemented by a summation and topographical identification. The first volume, including introductory essays, selected texts that mention many sites, and an annotated list of the sources, was published a few days before Tsafrir's final hospitalization. Volume II.1-2 contains all sites beginning with the letter A (much more numerous than for any other letter and including "Arabia, Arabs, and Nabataeans", which by itself accounts for c.350 pp.); vol. II is in the final stages of indexing. The first fruits of these efforts, co-authored with L. Di Segni and J. Green, appeared as the Tabula Imperii Romani: Iudaea • Palaestina: Eretz Israel in the Hellenistic, Roman and Byzantine periods - maps and gazetteer (1994).

\section{Urbanization}

Here Tsafrir's most important contribution lies in the large-scale excavations he conducted at Beth She'an/Scythopolis in 1980-81 and especially 1986-2003 in conjunction with G. Foerster, B. Arubas and many others. These excavations were part of the most extensive archaeological project ever conducted in the country. Scythopolis was the capital of Palaestina Secunda during the Byzantine period; Tsafrir's team excavated the civic center and amphitheatre, both of cardinal importance for understanding its urban development in the Roman, Byzantine and early Muslim periods. Architectural and other finds support a dynamic picture of urban development, including destruction and restoration, over several centuries. The findings are also relevant for understanding the cities of the Decapolis east of the Jordan River. Through his published articles, lectures and guided tours at Scythopolis, Tsafrir gained international renown as an expert on the urbanisation of these periods. To date, two volumes of final reports have appeared: the lamps and glass vessels. Three further volumes, devoted to the architecture and stratigraphy of the "Street of the Monuments", including the Nymphaeum, accepted by Qedem Reports as vols. IIIA-IIIC, are in the final stages of editorial work. The first of these includes Tsafrir's long introductory chapter on Scythopolis and its excavations.

Tsafrir also carried out surveys and excavations in the Judean Desert and the south: the churches of Pharan in the Sinai, the Hasmonean-Herodian fortress at Alexandrion/Sartaba (with Y. Magen), the caves at 'Ayn 'Arrub, a survey of the road from Avdat to Sha'ar Ramon (with Z. Meshel), and others. He also worked on the monasticism of Sinai and on the Monastery of St. Catherine. Prior to the ceding of the Sinai to Egypt in 1980, he assisted the Archaeological Survey of Israel in protecting sites.

His published works include a basic textbook, Eretz Israel from the destruction of the Second Temple to the Muslim conquest: archeology and art (in Hebrew) which, despite having been published in 1985, remains a basic textbook; an updated English version of c.600 pages is in the editing stage. He published 10 books and edited another 10, some jointly with colleagues. He published some 175 scholarly articles, many in English in IEJ and in Hebrew in Qadmoniot, and contributed many entries to the Encyclopaedia Biblica and the NEAEHL. His research was marked by a broad perspective and great erudition. Renowned as a book-lover, he authored a few volumes of belles lettres under the pseudonym Yoram Avi-Tamar. In 1976 he was awarded the Yitzhak Sadeh Prize for Literature for his book Injury (in Hebrew), in which he recorded his being heavily wounded in the Six-Day War and how he contended with his injuries in its aftermath. He continued as an education officer in the Reserve right up to the moment of having heart surgery. Despite walking on crutches since 1967, undeterred he visited an enormous number of sites throughout the Roman and Byzantine worlds.

Tsafrir was an inspiring and esteemed teacher, much beloved by his students. Unassuming and soft-spoken, he was naturally disposed towards collaboration and dialogue. He co-founded the School for Field Studies of the Midreshet Ben-Gurion at Sede Boqer in the early 1960s. From 1969 until his retirement in 2005 he taught at the Hebrew University's Institute of Archaeology, serving as its Director from 1989 to 1992 and as Professor of Classical and of Christian Archaeology. He inspired a whole generation of students to work on Byzantine sites across the country and especially in the Judaean Desert. His work on monasticism generated further work by his disciples (the late Y. Hirschfeld, J. Patrich on monasteries of the Judean Desert, U. Dahari on those of the Sinai peninsula) 
and others; the great surge of interest in monasticism starting in the 1980s was mostly due to his teaching. Other leading archaeologists in the Israel Antiquities Authority and at Israeli universities (e.g., R. Birger, R. Rubin, H. Goldfus, R. Talgam, B. Arubas) are among those whose Ph.D. theses he supervised or who have worked to continue his legacy. His wide range of interests, extending firmly into the Early Islamic period, was reflected in the Festschrift (see below) presented to him in 2009. He never reneged on his moral convictions, which include his public protest against destructive methods employed by archaeologists in the Arab Old City of Jerusalem. It was his fundamental belief that a political agenda should never dictate an archaeologist's emotions or a frantic pace of work.

A complete list of publications up to 2009 appeared in L. Di Segni, Y. Hirschfeld, J. Patrich and R. Talgam (edd.), Man near a Roman arch. Studies presented to Prof. Yoram Tsafrir (Jerusalem 2009) 1-8. The following is a selection:

\section{SELECTED BIBLIOGRAPHY}

\section{Books}

with Z. Meshel, The Nabataean road from Avdat to Sha'ar Ramon (Jerusalem 1977) [Hebrew].

Eretz Israel from the destruction of the Second Temple to the Muslim conquest, vol. II: Archaeology and art (Jerusalem 1984) [Hebrew].

Excavations at Rehovot-in-the-Negev, vol. I. The Northern Church (Qedem 25; Jerusalem 1988).

with L. Di Segni and J. Green, Tabula Imperii Romani - Judaea • Palaestina: maps and gazetteer (Jerusalem 1994).

with L. Di Segni, and J. Green, The Onomasticon of Iudaea-Palaestina and Arabia in the Greek and Latin sources vol. I (Jerusalem 2015).

three written as Yoram Avi-Tamar:

Injury (Tel Aviv 1975); revised edn., “Thirty years later” (Tel Aviv 2005) [Hebrew].

The sign of the sword (Jerusalem 1989) [Hebrew].

The Life of Joseph: an unpublished history (Tel Aviv 2000) [Hebrew].

\section{Edited works}

Z. Baras, S. Safrai, Y. Tsafrir and M. Stern (edd.), Eretz Israel from the destruction of the Second Temple to the Muslim Conquest vol. I (Jerusalem 1982) 144-79 [Hebrew].

D. Jacoby and Y. Tsafrir (edd.), Jews, Samaritans and Christians in Byzantine Palestine (Jerusalem 1988) [Hebrew].

Y. Tsafrir (ed.), Ancient churches revealed (Jerusalem 1993).

Y. Tsafrir and S. Safrai (edd.), The history of Jerusalem. The Roman-Byzantine period (Jerusalem 1999) [Hebrew].

M. Avi-Yonah, revised and edited by Y. Tsafrir, Pictorial guide to the model of ancient Jerusalem at the time of the Second Temple in the grounds of the Israel Museum, Jerusalem (Herzlia 2006).

\section{Articles}

"Monasticism at Mount Sinai," Ariel 28 (Spring 1971) 65-78.

"The location of the Seleucid Akra in Jerusalem," RBibl 82 (1975) 501-21.

with Y. Hirschfeld, "The church and mosaics at Horvat Berachot, Israel," DOP 33 (1979) 291-323.

"The Desert Fortresses of Judaea in the Second Temple period," The Jerusalem Cathedra 2 (1982) 120-45.

with J. Green, "Greek inscriptions from Hammat Gader," IEJ 32 (1982) 77-96.

"The transfer of the Negev, Sinai and Southern Transjordan from Arabia to Palaestina," IEJ 36 (1986) 77-86.

"The maps used by Theodosius: on the Pilgrim maps of the Holy Land and Jerusalem in the sixth century C.E.," DOP 40 (1986) 129-45.

"Christian archaeology in Israel in recent years," Actes du XIe congrès int. d'archéologie chrétienne (1986) (Rome 1989) vol. 2, 1737-70.

"Jérusalem romaine et byzantine," Les dossiers d`archéologie 165-66 (1991) 67-77 = "Jerusalem in the Roman and Byzantine period," in J. F. Perrot (ed.), Jerusalem - 5000 years of history (Paris 1992) 66-77.

"Monks and monasteries in southern Sinai," in Ancient churches revealed (Jerusalem 1993) 315-33.

with G. Foerster, "Nysa-Scythopolis in the Roman period: 'a Greek city of Coele Syria' - evidence from the excavations at Bet Shean," in ARAM Third Int. Conference: The Decapolis, $1992=$ ARAM 4 (1994) $117-38$. 
with G. Foerster, "From Scythopolis to Baysan - changing concepts of urbanism," in G. R. D. King and Averil Cameron (edd.), The Byzantine and Early Islamic Near East II: land use and settlement patterns (Princeton, NJ 1994) 95-115, figs. 14-25.

"Some notes on the settlement and demography of Palestine in the Byzantine period: the archaeological evidence," in J. D. Seger (ed.), Retrieving the past. Essays on archaeological research and methodology in honor of Gus W. Van Beek (Winona Lake, IN 1996) 269-83.

with G. Foerster, “Urbanism at Scythopolis-Bet Shean in the fourth to seventh centuries," DOP 51 (1997) 85-146.

"Procopius and the Nea Church in Jerusalem," AnTard 8 (2000) 149-64.

"Funding archaeological research: national-cultural values and objective knowledge - the Israeli experience," in M. Dörries, L. Daston and M. Hagner (edd.), Wissenschaft zwischen Geld und Geist (Max Planck-Institute für Wissenschaftgeschichte, Preprint 175; Berlin 2001) 123-31.

"The classical heritage in late antique Palestine: the fate of freestanding sculptures," in Y. Z. Eliav, E. A. Friedland and S. Herbert (edd.), The sculptural environment of the Roman Near East: reflections on cultural ideology and power (Leuven 2008) 117-42.

"70-638: The Temple-less mountain, in O. Grabar and B. Z. Kedar (edd.), Where heaven and earth meet: Jerusalem sacred esplanade (Jerusalem 2008) 72-99.

"Between David's Tower and Holy Zion: Peter the Iberian and his monastery in Jerusalem," in L. D. Chrupcala (ed.), Christ is here! Studies in Biblical and Christian archaeology in memory of Michele Piccirillo, ofm (SBF Coll. Maior 52; Milan 2012) 247-64.

with L. Di Segni, "The ethnic composition of Jerusalem's population in the Byzantine period (312-638 CE)," Lib. Ann. 62 (2012) 405-54.

"Further notes on the date of the earthquake of the year 749," in G. C. Bottini, L. D. Chrupcala and J. Patrich (edd.), Knowledge and wisdom: archaeological and historical essays in honour of Leah Di Segni (SBF Coll. Maior 54; Milan 2014) 111-20.

The editor of $J R A$ is most grateful to Leah Di Segni for providing additional information for this obituary. 